\title{
Horatio Alger and the GED (General Education Development) Diploma: Narratives of success in adult literacy education
}

\author{
JENNIFER A SANDLIN
}

\begin{abstract}
This article presents a qualitative analysis of stories of successful students told in adult literacy education. These stories follow a similar narrative, beginning with a protagonist who must overcome life obstacles, makes a conscious decision to change her life, rejects dependency, is of high moral character, remains optimistic despite challenges, and who ultimately succeeds through determination, perseverance, and hard work. After presenting these stories I argue that they are the latest manifestation of a genre of stories told for centuries in the United States and that comprise what many have called the 'American Myth of Success'. This myth, which has its roots in seventeenth-century Puritanism, states that every person, as a result of hard work and effort, can create the life they want for themselves. While these myths might provide hope for some adult literacy learners and teachers, I conclude that unquestioningly telling these success stories help to perpetuate the assumptions of this myth of success, and results in blaming adult learners for their own failure while ignoring social and structural factors that impede success.
\end{abstract}

\section{Introduction}

In this article I explore stories told by adult literacy teachers about successful students in adult literacy programs in the United States. These stories are common within both popular rhetoric about adult literacy as well as in the field of practice of adult literacy education. In popular rhetoric, these stories show the 'personal face' of adult learners, and appear in popular media (Quigley 1997). Within the field of adult literacy education, student success stories are often shared by keynote speakers at local, state, and national conferences (often accompanied by an appearance of the learners profiled in the stories). They are distributed through newsletters to state legislators, are printed on posters that appear as classroom decorations, are found in promotional materials distributed to adult learners, and are used as examples in curriculum materials. These stories chronicle the lives of students who have typically experienced great hardships, have enrolled in an adult literacy program, worked hard, and have succeeded in reaching 
their goals of obtaining a General Education Development diploma (GED) (which functions as a high school equivalency diploma in the United States and Canada) or finding employment. These stories can also be viewed as narratives that have a particular socializing function, as they 'introduce individuals or groups into a particular way of life through their authorial voice and legitimating functions' (McLaren 1995:91).

A closer look at these stories is needed because they help shape popular consciousness about how we should measure and judge a student's success and provide adult literacy students with a model of how to behave and what kind of person to become in order to achieve success in the classroom and in the world outside the classroom (St Clair 2004). These stories also help shape curriculum in adult education as well as contain ideological messages transmitted and negotiated in adult education classrooms. They provide the public and politicians with a vision of who adult literacy learners are and how they should act. The purpose of this research, then, was to explore these success stories, by addressing the questions: (1) What is their content? and (2) What purpose do they serve? In the discussion that follows I argue that these stories are the latest manifestation of a genre of success stories that have been told for centuries in the United States and that comprise the 'American myth of success'.

\section{What's the story?}

In order to understand these stories, I conducted a qualitative content analysis of 26 of them, gleaned from ten newsletters published by one state's Office of Adult Literacy (available at http://www.dtae.org/adultlit/perspectivesarchive.html), a federal monograph highlighting the Secretary's Awards for Outstanding Adult Education and Literacy Programs (U.S. Department of Education 2000), and from field notes from a research project I undertook in two education programs serving welfare recipients (Sandlin 2004, Sandlin and Cervero 2003).

I developed storymaps (Richmond 2002) for individual stories, in which I plotted major events outlined in the stories. I paid close attention to each story's orientation (setting and character), the abstract (what 'happens'), the complicating action (the narrator's evaluation of what happens), and the resolution (the final outcome) (Mishler 1986). Richmond (2002:2) explains that these storymaps can help to organise the narrator's 'recounting of past and present experiences and future intentions under the rubric of character, setting, events, conflicts, incidents, themes, and resolutions (or outcomes)', and thus help structure the individual stories.

Narratives, however, do not operate in a vacuum, divorced from social and political contexts. Narratives contain visions of the world, and these visions typically work in favor of dominant discourses and ideologies. 
The stories we tell and the language we use to tell them help create social reality (Chandler 2002). Green and Dixon (1996) argue that language is a way of 'inscribing the world, of framing an issue, and of talking perspectives into being' (294). Analyzing the stories to determine their plots did not fully address this more political view of narrative, however. I therefore also sought to determine these stories' ideological orientations - to ask 'in whose interests do these narratives operate?'. It seemed especially important to do so in this research because these stories were not written by students, but by teachers about their students.

In the context of this research, ideology refers to those worldviews that 'we tend to accept as natural and as common sense' (McLaren 1998: 180). The construction of ideology thus represents an 'intersection of meaning and power in the social world' (McLaren 1998:180). That is, ideologies can provide individuals with frameworks to help them make sense of the world, but these frameworks are always selective - pointing us towards one way of looking at the world while pointing us away from alternative portrayals. This more political view of narrative is thus informed by Williams' (1977) notion of the selective tradition and McLaren's (1995) discussion of the socialising function of narrative. McLaren (1995:91) argues that 'theories, ideologies, and social and institutional practices - and our relationship to them - are all informed by narratives'. He further explains that narratives help to create - to liberate and constrain - our identities. $\mathrm{He}$ states:

we use different kinds of narratives to tell different kinds of stories, but we also sanction certain narratives and discount others for ideological and political reasons. To a large extent, our narrative identities determine our social action as agents of history and the constraints we place on the identities of other. (McLaren 1995:89)

As I conducted my analysis, I saw that the stories followed a similar narrative structure, best represented by the genre of $m y t h$, recently described by St. Clair (2004:82) as a 'guiding story' which serves to 'help to shape beliefs and behavior to meet the needs of society'. More specifically, the stories I analyzed follow a kind of 'archetypal plot' similar to the quest, which typically involves the 'archetypal character' of hero. While the heroes of these success stories appear far removed from traditional mythological quest heroes, they are similar in that their lives are filled with struggle, and that they ultimately succeed through perseverance and strength. One particularly American spin on the hero's quest comes in the form of what some writers have called the 'American myth of success' - a 'deeply rooted cultural belief' infusing American society (Marsden 1978:38). The 
'American myth of success' posits that 'all men [sic], in accordance with certain rules, but exclusively by their own efforts, can make of their lives what they will' (Weiss 1988:3). This myth endures in the United States despite evidence casting doubt on the 'nature and extent of social mobility' in America (Weiss 1988:3).

Some academics assert that this myth originated in the 1600s, when, as British colonists began experiencing hardships upon arriving in America, they began to believe that the 'great promise held out by America was not ease, but hard work' (Marsden 1978:39). Despite the obstacles they encountered, however, hard work in the New World was seen to be worth the effort, as it was believed that hard work led to rewards that were impossible back in England. Settlers thus embraced the idea that 'the condition of even the lowest in America was far superior to the plight of the average man [sic] in England' (Marsden 1978:39). Puritan settler William Woods expressed these ideas succinctly, stating, 'the diligent hand makes rich' (New England's Prospects 1634, cited in Marsden 1978:39). This myth of success began appearing in American literature shortly after the first colonial settlements were established in the 1600s. These very early diary entries and settlement memoirs led to Puritan 'Guides to Living', which gave advice on how to achieve material success, which was tied to moral living and hard work. This genre continued with Benjamin Franklin's Poor Richard's Almanac in the 1700s, which contained such maxims as 'God helps them that help themselves' and 'The sleeping fox catches no poultry' (cited in Marsden 1978:41). The height of popularity of this genre occurred in the nineteenth century and is typified by the Horatio Alger's fictional 'rags-toriches' stories - which are centered on the ideals of prudence, frugality, and industry. While the details differ by story, Horatio Alger stories all contain the same general plot:

A poor boy (who is usually an orphan) is struggling to make ends meet as a bootblack, errand-runner, or some sort of street merchant. Though the hero is almost always on one of the lower rungs of the economic ladder, his personal moral code is quite high. He is always generous, self-sacrificing, honorable, and gentlemanly. He has an innate sense of self-worth and a good deal of respect for others, especially those who are in positions of authority ... This combination of innate moral goodness and a mature devotion to diligence pays off for them in the end. In the process of seeking his fortune, the Alger hero must often confront an assortment of thieves ... seeking their own fortunes in unscrupulous ways. But the hero's common sense, which seems to derive from his innate sense of what is right and wrong, always saves him from ruin, and what he 
might lose in material gain, by taking a moral stance, is compensated for later. (Marsden 1978:42)

The inspirational writings of twentieth century authors such as Norman Vincent Peale continued this tradition of the American success myth, which can be seen today in the vast numbers of self-help books on the market (Weiss 1988).

A typical adult literacy student success story goes something like the one that follows, which appeared in a quarterly newsletter sent to adult literacy teachers and state legislators by one state's Office of Adult Literacy. It tells the story of a former Temporary Assistance to Needy Families (TANF, or what is commonly referred to in the U.S. as 'welfare') recipient, Terri:

Terri could have taken an easier path, going from agency to agency letting others solve her problems. Instead, she chose to take responsibility for her life and the lives of her three children by using the resources of the departments of Technical and Adult Education, Human Resources, and Labor to overcome obstacles and become self-sufficient. In a few short weeks, she learned through difficult experience the value of education as she prepared to become part of [the state's] workforce.

Terri, 28, is a 1998 local Technical Institute graduate. She began receiving TANF in January. By June, she had passed her GED exam and participated in job readiness and computer classes, and completed work experience. Only then did she land a job. Terri's is a story of determination born of need and hope that grew out of despair. She became a single mother in October 1997 when her husband abandoned her and their three children, then ages five, seven, and eight. Lacking skills and a high school diploma, she searched unsuccessfully for a job. After two months, she turned to the County DFCS [Department of Family and Child Services, which administers various welfare programs] for help.

Her case manager sent her to the local Technical Institution Adult Education Center for GED preparation, basic computer classes, and job readiness workshops. Studying at the center prepared Terri to take and pass the GED exam. At the same time, she took a computer class and participated in job readiness programs. During the same period, Terri entered a DFCS Work Experience Program. After completing the GED, she went to her Work Experience site in the mornings and 
attended the computer skills classes in the afternoon. At the end of ninety days of work experience at the Professional Nursing Services, the owner hired her.

The path Terri followed was full of obstacles. Raised by her grandmother and an aunt, she knows little about the parents who deserted her. She quit school in the $10^{\text {th }}$ grade, got pregnant at 16, and married. Her three children were born in less than three years. Her husband's truck-driver job took the family to Wayne County. When she was abandoned, Terri was left without a support system or family. At the GED graduation, her guests were three small children sitting on the first row of the auditorium.

In the job readiness workshops, she was enthusiastic and an active participant, according to the director. Her dedication to meeting the goals she set is evident in her class attendance record. 'She attended 100 percent of the classes in the six week computer course', the director said. 'She is very capable, highly motivated and not afraid to try new things. Moreover, she has a very pleasant personality, gets along well with other people, and is quite modest about her accomplishments.' Terri went to work December 1, 1998 in the adult literacy office as a data entry clerk. She plans to enroll Spring quarter in the office technology program. She has learned that her best resource for competing in the workforce is her education. (Wren 1999)

\section{Overcoming obstacles}

This story has all of the elements typically found in similar success stories. First, in the stories protagonists must overcome life circumstances, including getting pregnant at a young age, having to care for a sick relative, suffering from learning disabilities or physical disabilities, and becoming homeless or jobless. The harder off the student is, the more compelling his or her story, and the more 'hard-earned' the success is viewed. In addition to Terri's story, above, another example of overcoming obstacles comes from the story of a student profiled in the Secretary's Awards for Outstanding Adult Education and Literacy Programs:

In 1989, when she was just 17 and a $10^{\text {th }}$ grader, Sherry became pregnant. Not only did she leave school, but her mother no longer wanted her at home. Sherry moved to Florida with her boyfriend. Things went well for a while, but the young couple's happiness was short lived. When her son's father abused her, 
Sherry had no choice but to return home. (U.S. Department of Education 2000a:15)

\section{Making a conscious decision to change}

In these success stories, the protagonist must make a conscious effort to overcome the difficulties and obstacles they are facing. In Terri's story, we learned that she was not happy with her situation, so she decided to change it. A similar decision is seen in the following excerpt from the story of Deborah, told in a state Office of Adult Literacy's newsletter:

I cared nothing about the world outside my bedroom, including my kids. I isolated myself, not answering the telephone or the front door,' she said. For weeks, Deborah would not get out of bed, unless it was absolutely necessary. Then, one day, her twoyear-old approached her carrying a can of beer. He placed it by the bedside and said, 'Here's your beer, Mommy.' The most painful feeling came over her, and she found the courage to get out of bed, and dispose of all the alcohol in the house. 'I realised I was ruining not only my own life, but my children's lives as well.' (Pierce 2000)

Before positive changes can occur in a learner's life, he or she has to believe she can change. Thus, changes are linked with the power of positive thought and a determined mind. Changes do not occur through happenstance, but only after the protagonist makes up his or her mind to proactively address certain problems.

\section{Rejecting dependency}

As women on welfare are increasingly moving into adult literacy classrooms (Dirkx 1999), many of the success stories told are about students who come to adult literacy from the welfare system. When such protagonists make a conscious decision to change, in this process they typically reject 'dependency on welfare' and strive towards 'self-sufficiency'. The women in these stories represent the 'ideal TANF recipient' - they strive for selfsufficiency and ultimately reject dependence on the government. In these stories, these single mothers all desire to make a better life for their children and for themselves. Despite many of the life obstacles these women have faced, only two women are profiled as long-term welfare recipients. The rest are portrayed as struggling to make ends meet and using welfare as a last resort, after trying other options like moving in with family members or scraping by. For instance, we see in the story of Glenda how one mother gave up her welfare benefits in order to stay in school a little while longer and earn her degree. In this story, halfway through a four year nursing 
program, Glenda was told her welfare benefits would be cut unless she decided to give up her welfare benefits and struggle through on her own, without government help. In the story we hear that 'Life was tough, but Glenda's grades were excellent and most of all, her self-esteem was growing stronger and stronger. It was Glenda's persistence that allowed her and her family to carry on. Basic necessities were obtained by standing in line at the community food pantry and by simply doing without things other families take for granted' (U.S. Department of Education 2000b:30). In many of these stories, part of striving towards self-sufficiency includes a short stay on public assistance. While some learners opt to use welfare benefits, it is clearly pointed out in the stories that they used welfare only for a few short months, as a stepping stone to employment. In the stories, it is deemed morally correct to use public assistance as a temporary stop-gap measure to help a learner get back on her feet. There is an implicit judgment against using welfare for a longer period of time or being 'dependent' on 'the system.'

\section{Of good moral character}

The learners in these stories are likeable - they get along well with others and have friendly personalities. Many learners are also described as warm, honest, and decent people. For instance, in the story of Roselunde, we learn about her positive qualities:

It isn't just the drive for learning that makes Roselunde an extraordinary person; it is her outgoing personality and her curious and empathetic nature that make sets her apart. When she walks into a room; she smiles, talks to people, and remembers the little things that people have told her. Most of all it is her infectious sense of humor that others quickly observe. (U.S. Department of Education 2000c:5)

Protagonists are often also described as being religious, and particularly possessing a strong Christian faith. We learn, for example, about Emilia's religious commitment in her story:

The students in her class find Emilia to be a warm and generous woman who gives to her church, family, friends, and community. She conveys a deep respect for education and inspires others to do the same. Those who know her best describe her as being a thoughtful person with a kind word for everyone she meets. (Drew 2000) 
The learners in these stories are, above all, people with high morals, even if sometimes their 'former lives' are portrayed as being riddled with alcohol or drug abuse.

\section{Remaining optimistic}

The learners in these stories typically have the ability to draw upon their strong and moral characters to remain optimistic, despite difficult circumstances. For instance, Terri in the story above, devoted time and energy to schoolwork, and managed to remain hopeful and determined even though she was going through hardships. This optimism is also seen in the story of Cassie: 'This eternally optimistic young woman can pack more into her mornings than most people can do all day. Cassie makes it look easy, does it all with a smile that is contagious' (Morton 2000). Another example of a learner keeping a positive outlook despite life difficulties is Brenda:

The youngest member of her household is her eleven-year-old son, Bobby, who suffers from cerebral palsy and requires constant care. Sometimes, Brenda comes to class exhausted if Bobby has had a restless night, but maintains a positive outlook and strong work ethic in the classroom. Using her lunch break to assist fellow students with math problems, she is a constant source of encouragement for her classmates. (Vonier 2000)

\section{Succeeding through determination, perseverance, and hard work}

These success stories have happy endings, as protagonists achieve success as a result of their optimism, moral character, perseverance, and hard work. In the story of Emilia, for instance, we see a determined protagonist who ultimately succeeds because of hard work:

Despite encountering numerous obstacles, she is determined to pass the GED test. Every task is viewed as a challenge to be met with grace, dignity and perseverance. Through hard work and dedication, Emilia has enriched her own life as well as the lives of her friends and family. She never lost sight of making her 'dreams come true'. She is goal oriented and continues to attend adult education classes. (Drew 2000)

These stories make it clear that although sometimes the protagonists are helped by other people, institutions, and agencies, success is ultimately achieved as a result of learners' own personal effort. This is stated directly in 
Glenda's story: 'Although she has had help from a significant number of people, her move to a more hopeful and prosperous life is largely due to her hard work' (U.S. Department of Education 2000b:30).

The successes achieved by the learners in these stories typically consist of getting off welfare, getting the GED, and finding employment. These stories also typically describe a change in the self-perception of the protagonist - there is usually some kind of increase in self-esteem that is a result of achieving these successes. For instance, we see in Roselunde's story evidence that hard work leads to the rewards of a full-time job with benefits:

For three years Roselunde attended classes faithfully and every year she received attendance awards ... Roselunde is a good worker and she is committed to her tasks. Not surprisingly, the Visiting Nurse's Association noticed her dedication and promptly offered her a full-time day job with very good benefits. (U.S. Department of Education 2000c:5)

\section{The American myth of success: placing success stories in context}

Success stories of the kind told in adult literacy programs are not new. In fact, stories highlighting similar paths to success have been told throughout the history of the U.S. and comprise the 'American myth of success' (Wyllie 1954, Cawelti 1965, Madden 1970, Huber 1971). This myth states that anyone who exhibits the right combination of hard work and effort can create the life they want for themselves. The term 'myth' in this context refers to a 'complex of profoundly held attitudes and values which condition the way men [sic] view the world and understand their experience' (Weiss 1988:3-4), and does not simply signify something 'false.' The American myth of success is a particular ideological viewpoint upholding these beliefs: 'to work hard in order to succeed in competition; those who work hard gain success and are rewarded with fame, power, money, and prosperity; [and] since there is equal opportunity, it is claimed, those who fail are guilty of either insufficient effort or character deficiencies' (DeVitis and Rich 1996:5). This myth of success is deeply ingrained in the collective U.S. psyche. While a great deal of empirical evidence has criticised the veracity of this viewpoint, 'the idea that ours is an open society, where birth, family, and class do not significantly circumscribe individual possibilities, has a strong hold on the popular imagination' (Weiss 1988:3).

The myth of success has been organised around different 'strands' throughout the last several centuries, each emphasising a different 'way' or 'path' to success. The most popular of these strands have been called 'the character ethic,' 'the personality ethic,' and the 'mind-power ethic' (DeVitis 
and Rich 1996). While the paths to success are different, these strands are similar in that they all stress the power of the individual to achieve success. Of the different 'strands' of the success myth, the two most reflected in the adult literacy success stories are the 'character ethic' and the 'mind-power ethic'.

\section{The character ethic}

The character ethic is the oldest manifestation of this myth, having its roots in seventeenth-century Puritanism. This ethic represents a 'group of traits and a way of life considered to have significance and moral quality,' including 'perseverance, industry, frugality, sobriety, punctuality, reliability, thoroughness, and initiative' (DeVitis and Rich 1996:11). While success stories stressing the character ethic differ throughout time concerning their religious or secular contexts, they all stress the link between 'proper' living and worldly success.

The focus on moral character as a path to success started with Puritan inspirational writings in the seventeenth century, a trend that continued into the $18^{\text {th }}$ century with Benjamin Franklin's 'Guides to Good Living.'

Evidence of the character ethic is also found in the McGuffey readers which appeared in 1836 and which were widely read by school children throughout the United States during the following century. These readers were some of the earliest and widest read books of what came to be known as the 'self-help genre' and contained character ethic ideas such as that 'opportunity existed for everybody' and that being honest and of good character is the 'surest, the happiest, and the best' path towards success (Weiss 1988:34).

The character ethic reached its peak in the nineteenth century with the 'rags-to-riches' literature tradition, which included its most famous examples - the fictional stories of author Horatio Alger. This tradition focused around the behavioral patterns enjoyed by the Protestant ethic (Weiss 1988). While in many Alger stories the heroes gain success due to a turn of fate, financial success only appears accidental. In fact, it is not accidental at all; it is grounded in the morality of the protagonist. In Alger's world, 'virtue is the necessary antecedent to good fortune. It alone is the spring which triggers the lucky payoff' (Marsden 1978:44).

\section{The mind-power ethic}

What has been termed the 'mind-power ethic' is also present in the adult literacy success stories. The mind-power ethic has its roots in the early twentieth century 'New Thought' movement which arose as economic upward mobility in the United States was no longer based on an entrepreneurial model, but was shifting to a white-collar business model. Opportunities for individuals to 'make it' seemed to be diminishing. With 
the growing industrialization of the country came a 'naturalistic world-view which contradicted theological notions of a purposive and moral universe' (Weiss 1988:129), where individuals were rewarded on the basis of their moral worth, a worldview held by many of the writers in the character ethic tradition. As a response to these changes, a spontaneous religious movement emerged, called variously 'New Thought, Mind, Mental Science, Harmony, Metaphysical Healing, and Mind Cure' (Weiss 1988:130). Instead of focusing on moral virtue, this mind-power movement focused on the power of the individual to use positive thinking to achieve success. One of the early proponents of this movement, Bolton Hall, argued that the reason successful people succeed is that they expect to succeed and then do succeed. Advice about how to succeed changed from encouragement to overcome 'objective obstacles' and toward getting rid of the 'subjective inhibitions' within one's mind (Weiss 1988:168).

Thus in the mind-power movement there was a shift away from the idea that the keys to success were character traits and towards the idea that, instead, states of mind determined whether one succeeded or failed. This faith in the power of the mind to determine success has been a lasting legacy from the mind-power ethic, and can be seen in subsequent movements echoing the same general idea, including the development of psychotherapy and the work of mind-power 'gurus' such as Emile Coué (1924) (who originated the mantra 'Day by day, in every way, I am getting better and better') and Norman Vincent Peale's (1952) 'power of positive thinking' movement. This tradition is alive and well today, as evidenced by the popular 'self-help' genre of books, encouraging success in everything from weight-loss to finding love to smoking cessation to growing rich through positive thinking (Harris 1999, Johnson 1999).

\section{Unpacking success stories}

The stories of successful students told in adult literacy circles contain elements of both the character ethic so prevalent in Horatio Alger stories and the mind-power ethic popular in more recent rendition of the myth. In the adult literacy stories those who are successful are good, honest, and moral people who work hard, think positively, and persevere even through desperate times. These stories promote the idea that success comes about as a result of having a particular kind of character, remaining positive, never giving up, and working hard.

However, because all narratives also contain a particular view of the way the world is or should be, I would now like to return to the questions I posed above - 'what is the purpose of these stories', and 'in whose interests do they operate'? Quigley (1997) states that on one hand these stories can serve as inspiration to adult learners and adult literacy programs - even the 'most cynical of our veteran practitioners [are] touched by the success 
stories of learners' (243). Quigley (1997:31) further explains some of the reasons literacy teachers tell these stories:

Beyond trying to lobby through 'gut-wrenching testimony', there is a deep gratification in hearing the successes of at least some of our learners. Ours is a caring field and a field of optimism and romance. Selected heroic victims fulfill a personal need in most of us who commit time and energy to this field.

These stories almost certainly serve to inspire students and teachers, to give them hope to overcome obstacles in their way to success. In American society, Robertson (1980:151) suggests that the myth of upward mobility through hard work symbolises freedom - and upholds the peculiarly American ideal of the 'independent individual'. This ideal stands in contrast to the lives Americans actually lead - which are often 'immobile and frustrating' (Robertson 1980:151). Thus the myth offers hope to people. Those who have least power, money, and status:

have known the facts for a long time, by living with them from day to day. But they are not content with facts, for facts are dull companions, and dangerous besides. Men [sic] on the bottom need dreams. (Wyllie 1954:174)

However, these myths also serve purposes that do not necessarily work in the favor of adult learners, literacy teachers, or adult literacy programs. The stories, like their predecessors, draw upon two main ideologies to create their vision of the way success occurs: individualism and meritocracy. Individualism is a set of ideas 'emphasizing the importance of the individual and the individual's interests' and is used to 'describe a political philosophy usually described as 'liberal individualism' that stresses the importance of the individual and the value attached to individual freedom and individual choice' (Marshall 1998:304). Meritocracy is 'a social system in which status is achieved through ability and effort (merit), rather than ascribed on the basis of age, class, gender, or other such particularistic or inherited advantages. The term implies that the meritorious deserve any privilege which they accrue' (Marshall 1998:410).

The focus on individualism and meritocracy in these success stories parallel an increased focus on self-sufficiency found in two policy initiatives that have greatly influenced the field of adult literacy education in the United States, the 1996 Personal Responsibility and Work Opportunity Reconciliation Act (also know as President Clinton's Welfare Reform Act), which linked adult literacy education and welfare-to-work education more closely than ever before, and the 1998 Workforce Investment Act, which 
consolidated all adult literacy education under the umbrella of workforce development. In this policy arena, there is increasing preoccupation with self-reliance, which reflects the interests of a strong conservative movement that began in the 1980s in the U.S., and which has worked to dismantle any remnants of a safety net leftover from the 1960s 'War on Poverty' era of U.S. history (Micklethwait and Wooldridge 2004).

In the literacy success stories, as well as in the public policy arena, the narratives promoted, like all ideologies, are not natural, neutral, or commonsensical. Instead, they serve the ideological purpose of selecting for us one way of looking at the world, while distracting us from other possible ways of viewing the world. The narratives promoted reflect a conservative agenda that 'scorns the ideal of collective empowerment and social responsibility in the name of economic realism' (McLaren 1995:103). Educational narratives within this age of conservatism 'are aimed at producing compliant workers and loyal consumers' (McLaren 1995:103) and uphold a 'master narrative' constructed by the New Right which outlines who their ideal subjects are, and how these subjects 'personify the sacred values of religion, hard work, health, and self-reliance' (Denzin 1991:150, emphasis mine). Citing Denzin (1991), McLaren (1995) argues that contained within this master narrative is the 'ancient myth' of rugged individualism. The ideology of self-reliance found in these narratives is linked to domination and unequal power relations because it reifies our current system, instead of illuminating how this system was historicallyproduced. These myths run the 'risk of oversimplification', which can result in 'restricting one's critical capacity for raising important questions and challenging existing forms of knowledge, valuation, and social organization' (DeVitis and Rich, 1996:167). Because these myths ignore issues of power, they serve to 'camouflage the ubiquitous harshness of social repression' (DeVitis and Rich, 1996:169). In the realm of education, perpetuating such myths sets up false expectations for students and places blame for failure solely on learners, ignoring contextual social, political, and economic factors. As adult literacy educators and program directors through the telling of these stories focus on self-sufficiency and the ability of adult learners to 'lift themselves up by the bootstraps', they may be unwittingly obviating the perceived need for adult literacy programs, and thus further jeopardizing what has become already scarce funding. Funders could ask, 'If learners succeed solely as a result of their own hard work, why do they need literacy programs?'

\section{What's the alternative?}

It is easy enough to critique these myths; a much more challenging task involves envisioning an alternative. What does critiquing these myths mean for the practice of adult education? If teachers do not tell these stories 
in their classrooms and when lobbying politicians, what stories should they tell instead?

What is the alternative for an adult literacy educator not wishing to perpetuate myths of success in their classroom? Does not upholding these myths necessarily mean taking away any hope or inspiration for learners, and presenting them with a bleak picture of their futures? Critical educators must ask themselves: 'what is worse - holding out false hopes to students in the form of success myths or presenting a bleak structural analysis of economic opportunities and crushing any hope for the future?' One huge challenge for critical adult literacy educators who wish to problematise such myths is how to do this without simultaneously taking away any incentive to try or any hope for the future. There are no clear answers, but hopefully educators struggling with these issues can begin to create a classroom discourse that avoids the simple dichotomy of either promoting false expectations or dooming students to failure.

How might one achieve this? Adult literacy educators could try creating critical discussions in their classrooms around these success stories, perhaps tied into reading and discussing their historical precedents, including the Horatio Alger stories. Through group discussions of success stories, students could first come to a collective understanding of the hidden or unstated assumptions underlying these stories. They could then begin questioning these assumptions through a comparison of the stories with their own life biographies and biographies of people they know. Discussions could address the alternative endings found in many real-life stories - what about people who work hard, have positive attitudes, and still do not succeed? Or people who gain material success despite lacking a work ethic or a moral character? The reasons for these stories remaining popular for hundreds of years could be discussed, and set into both a broad context of the way our economic system works, and also into a more localised context involving a realistic examination of local employment trends and opportunities.

Students could then be invited to create alternative success stories, and to work together to envision different ways to describe and/or achieve success. Discussions combined with action research projects around unemployment in their local areas could lead to new understandings about the connections between education and employment.

Would the new understanding arising from exposure to a different discourse about education, work, and success present a bleak picture for students? Perhaps, but through the process of group inquiry, students would have been challenged to think critically about issues affecting their daily lives, and to work together to come up with alternative points of view. While exploring the possibly grim realities of employment opportunities and the social, political, and economic contexts of work might raise more issues than it solves for learners, it seems that the alternative - continuing 
unproblematically to perpetuate myths of success - does not serve students well, as it positions failure as the sole fault of lack of effort or character deficit.

With regard to the 'public face' adult literacy practitioners and programs should wear, Quigley (1997) reminds us that adult literacy teachers and programs are 'part of the myth-making process' (8). He urges that, in order to operate in the best interest of learners, and to create a more stable infrastructure for the field, adult literacy educators need to pay close attention to how the field is perceived in society and how we help shape that perception. Over time adult literacy educators might have moved away from the 'soft maternalism' discussed by Quigley (1997) and are now focusing on success stories on self-sufficiency. While it is commendable to no longer portray adult literacy learners as helpless and in need of nurturing, embracing stories that uphold neo-conservative ideologies of individualism and self-reliance does not seem to be the answer, either. A decade later, Quigley's statement that 'simplistic analyses and the assumptions behind them are an insult both to our learners and to our profession' (240) still resonates; adult educators need to continue to heed Quigley's call to reflect on, and challenge, its central values.

\section{References}

Cawelti, John G (1965) Apostles of The Self-Made Man, University of Chicago Press, Chicago.

Chandler, David (2002) Semiotics: The basics, Routledge, London.

Coué, Emile (1924) Conscious Auto-Suggestion, TF Unwin, London.

Denzin, Norman K (1991) Images of Postmodern Society: Social theory and contemporary cinema, Sage, Newbury Park, CA.

DeVitis, Joseph L, and Rich, John Martin (1996) The Success Ethic, Education, and the American Dream, SUNY Press, Albany, NY.

Dirkx, John M (1999) New Skills for Literacy Educators, in Martin, Larry and Fisher, James, eds, New Directions for Adult and Continuing Education, The Welfare-To-Work Challenge For Adult Literacy Educators, Jossey-Bass, San Francisco, no 83, pp 83-94.

Drew, H R (Winter, 2000) Introducing Emilia, Perspective: From the Office of Adult Literacy, retrieved from www.dtae.org/adultlit/Perspectives6/emilia.html

Green, J and Dixon, G (1996) Language of Literacy Dialogues: Facing the future or reproducing the past, Fournal of Literacy Research, vol 28, no 2, pp 290-301.

Harris, Carol (1999) Think Yourself Slim: A unique approach to weight loss, Element Books, Ltd, Shaftesbury, England. 
Huber, Richard (1971) The American Idea Of Success, McGraw-Hill, New York.

Johnson, Debbie (1999) Think Yourself Loved, Unity School of Christianity, Unity Village, MO.

Madden, David (1970) American Dreams, American Nightmares, Southern Illinois Press, Carbondale, IL.

Marsden, Madonna (1978) The American Myth of Success: Visions and revisions, in Nachbar, J, Weiser, D and Wright, John, eds, The Popular Culture Reader, Bowling Green University Popular Press, Bowling Green, $\mathrm{OH}$.

Marshall, Gordon, ed, (1998) A Dictionary of Sociology, (Second ed) Oxford University Press, Oxford.

McLaren, Peter (1995) Critical Pedagogy and Predatory Culture, Routledge, New York.

McLaren, Peter (1998) Life in Schools: An introduction to critical pedagogy in the foundations of education, ( $3^{\text {rd }}$ ed), Longman, New York.

Micklethwait, John and Wooldridge, Adrian (2004) The Right Nation: Conservative power in America, The Penguin Press, New York.

Mishler, Elliot G (1986) The Analysis of Interview-Narratives, in Sarbin, T, ed, Narrative Psychology: The storied nature of human conduct, Praeger, New York.

Morton, R (Summer, 2000) Cassie Salter Beats the Odds, Perspectives: From the Office of Adult Literacy, retrieved from www.dtae.org/adultlit/Perspectives7 / cassie.html

Peale, Norman Vincent (1952) The Power of Positive Thinking, Prentice-Hall, Englewood Cliffs, NJ.

Pierce, D (Summer 2000) Like a Phoenix Rising (Story of Deborah), Perspectives: From the Office of Adult Literacy, retrieved from: www.dtae.org/adultlit/Perspectives7/phoenix.html

Quigley, B Allan (1997) Rethinking Literacy Education, Jossey-Bass, San Francisco.

Richmond, Heather J (2002) Learner's Lives: A narrative analysis, The Qualitative Report, vol 3, retrieved from: www.nova.edu/ssss/qr/qr73 /richmond.html.

Robertson, James Oliver (1980) American Myth, American Reality, Hill and Wang, New York.

Sandlin, J A (2004) 'It's All Up To You': How welfare-to-work educational programs construct workforce success, Adult Education Quarterly, vol 54, no 2, pp 89-104.

Sandlin, J A, and Cervero, R M (2003) Contradictions and Compromise: The curriculum-in-use as negotiated ideology in two welfare-to-work classes, International Fournal of Lifelong Education, vol 22, no 3, pp 249-265. 
St. Clair, Ralf (2004) Success Stories: Aspirational myth in the education of adults, International Fournal of Lifelong Education, vol 23, no 1, pp 81-94.

U.S. Department of Education (2000) Outstanding Results - Tomorrow's Challenge: The secretary's awards for outstanding adult education and literacy programs, Office of Vocational and Adult Education, Washington, DC.

U.S. Department of Education (2000a) Adult Learner Success Story: Sherry Sanders, in Outstanding Results - Tomorrow's Challenge: The secretary's awards for outstanding adult education and literacy programs, Washington, DC: Office of Vocational and Adult Education, p 15.

U.S. Department of Education (2000b) Adult learner success story: Glenda Borgen, in Outstanding Results - Tomorrow's Challenge: The secretary's awards for outstanding adult education and literacy programs, Office of Vocational and Adult Education, Washington, DC, p 30.

U.S. Department of Education (2000c) Adult learner success story: Roselande Jeanbaptiste in Outstanding Results - Tomorrow's Challenge: The Secretary's awards for outstanding adult education and literacy programs, Washington, DG: Office of Vocational and Adult Education p 5.

Vonier, M L (Summer 2000) Who is the Typical Adult Literacy TANF student? (Story of Brenda), Perspectives: From the Office of Adult Literacy, retrieved from: www.dtae.org/adultlit/Perspectives7/tanf.html

Weiss, Richard (1988) The American Myth of Success: From Horatio Alger to Norman Vincent Peale, University Of Illinois Press, Urbana, IL.

Williams, Raymond (1977) Marxism and Literature, Oxford University Press, Oxford, UK.

Wren, D (Winter/Spring 1999) Profile of Self-Sufficiency (Story of Terri), Perspectives: From the Office of Adult Literacy, retrieved from: www.dtae.org/adultlit/Perspectives4/self.html

Wyllie, Irvin (1954) The Self-Made Man in America, Rutgers University Press, New Brunswick, NJ. 